\title{
A espionagem aliada no Brasil durante a Segunda Guerra Mundial: Cotidiano e política em Belém na visão da inteligên- cia militar norte-americana
}

\author{
Allied espionage in Brazil at World War II: Everyday life and \\ Politics in Belém according to the US Military Intelligence
}

\begin{abstract}
Alexandre Fortes*
Resumo: O trabalho da inteligência aliada no Brasil durante a Segunda Guerra Mundial produziu documentos altamente relevantes, que há várias décadas vêm sendo utilizados pelos historiadores dedicados à análise do período. A montagem e funcionamento das redes de espionagem estabelecidas pelas diversas agências, entretanto, ainda não foi objeto de um estudo sistemático. O presente artigo, resultante de uma pesquisa mais ampla sobre os impactos sociais e políticos da Segunda Guerra Mundial no Brasil, busca contribuir nesse sentido a partir da análise de um relatório minucioso escrito por dois agentes da inteligência militar norte-americana que atuaram em Belém entre maio e novembro de 1942 .
\end{abstract}

Palavras-chave: Segunda Guerra Mundial; Bases aéreas; Inteligência aliada; Belém; Afundamento de navios brasileiros; Nacionalismo de Massas

\footnotetext{
* Professor Adjunto, Departamento de História, Universidade Federal Rural do Rio de Janeiro (UFRRJ), Brasil. Doutor em História pela Universidade Estadual de Campinas E-mail: fortes.ufrrj@gmail.com
} 


\begin{abstract}
The work of the Allied intelligence in Brazil during World War II produced extremely relevant documents, which for many decades have been used by historians committed to studying that moment. The setting up and the operation of the espionage networks built by the various agencies, however, have not yet been subjected to a systematic analysis. This article, resulting from a larger research project focusing on the social and political impacts of World War II in Brazil, aims to contribute in that direction based on the examination of a detailed report written by two US military intelligence agents that were on duty in Belém from May to November, 1942.
\end{abstract}

Keywords: World War II; Air bases; Allied Intelligence; Belém; Sinking of Brazilian Ships; Mass Nationalism

"Abaixa o braço,

Deixa de cena,

Lugar de palhaçada é no cinema.

Seu Adolfito, pra que tanta valentia

Se nós queremos a democracia?

Dona Cecília já se convenceu

Que os aliados estão no apogeu.

Vocês do Eixo muito breve saberão

Que as Américas unidas vencerão.

Que bão! (breque)"

Abaixa o braço, Elpídio Viana e Nelson Trigueiro, 1944

Objeto de estudo consagrado nos trabalhos de especialistas em relações internacionais e estudos militares, jornalistas e memorialistas, o envolvimento do Brasil na Segunda Guerra Mundial apenas recentemente passou a receber maior atenção por parte da história social. A vasta produção historiográfica sobre a relação entre o Estado Novo e os trabalhadores, por exemplo, por várias décadas passou ao largo do debate internacional sobre o impacto das experiências de Guerra Total no estabelecimento de sistemas de regulação do trabalho e no fortalecimento de direitos sociais. ${ }^{1}$

Resultante do projeto de pesquisa "Os impactos da Segunda Guerra Mundial na reconfiguração das relações de classe no Brasil", este artigo baseiase em documentação inédita: um relatório de 86 páginas, acompanhado por dezenas de fotos, registrando a atuação de dois agentes especiais do Counter Intelligence Corps do Exército norte-americano em Belém, entre maio e novembro de $1942 .{ }^{3}$

A análise dessa fonte peculiar possui dois objetivos. Em primeiro lugar, ao expor detalhes sobre a atuação da inteligência militar norte-americana no Brasil, lançamos luzes sobre um dos aspectos menos conhecidos da aliança 
estabelecida entre os dois países naquele momento histórico. Em segundo lugar, reconstituímos aspectos dos processos sociais e políticos que perpassam um importante centro urbano brasileiro num momento em que a experiência da conflagração global passa a afetá-lo de forma cada vez mais intensa.

Esperamos que esse exercício demonstre o quanto a integração de campos de conhecimento especializado distintos pode renovar nossa compreensão de conjunturas históricas decisivas e criar as bases para a redefinição dos termos do debate acadêmico sobre elas.

\section{A espionagem aliada e o Brasil}

$\mathrm{O}$ aspecto mais bem analisado pela bibliografia acadêmica sobre a espionagem aliada no Brasil durante a Segunda Guerra Mundial diz respeito à atuação do Federal Bureau of Investigation (FBI), dirigido pelo lendário Edgar J. Hoover. Frank McCann, em seu clássico livro sobre a aliança Brasil-Estados Unidos, menciona que já em 1938 o ministro das Relações Exteriores do Brasil, Oswaldo Aranha, solicitou ao subsecretário de Estado norte-americano Sumner Welles o envio de um agente o FBI ao Brasil para "organizar um serviço secreto especial". ${ }^{4}$ Já Martha Huggins registra que em 24 de junho de 1940 Hoover assumiu "completa responsabilidade por toda atividade norte-americana de inteligência no Hemisfério Ocidental", com a criação do Special Intelligence Service (SIS). A iniciativa, determinada em uma "orientação telefônica" pelo presidente Franklin D. Roosevelt, foi ratificada posteriormente em um memorando assinado por Adolf A. Berle, então subsecretário de Estado e posteriormente embaixador no Brasil. ${ }^{5}$

O suposto monopólio latino-americano de Hoover, entretanto, não impedia que outras agências norte-americanas atuassem na região, criando conflitos de atribuições que, em certos casos, o próprio Roosevelt foi chamado a arbitrar. Antônio Pedro Tota relata que em 1941 Nelson Rockefeller, chefe do Office of the Coordinator of Inter-American Affairs (OCIAA) e William Donovan, então Co-ordinator of Information (COI), desentenderam-se em relação à realização de transmissões de rádio para a América Latina. Diante do impasse, Roosevelt decidiu que "notícias e material inspiracional" para as repúblicas americanas seriam feitas apenas pelo OCIAA. ${ }^{6}$ Tota extrai do embate entre Rockefeller e Donovan a conclusão de que a OSS "manteve o mundo inteiro, sem a América Latina", e considera superficiais e grosseiras as análises dos agentes de Donovan sobre a situação política e social brasileira (particularmente no aspecto racial), assim como suas recomendações em relação aos cenários para a ação militar norte-americana no país. ${ }^{7}$ Parece-nos, porém, que as onze caixas de documentos da OSS referentes ao Brasil no período ${ }^{8}$ ainda merecem uma avaliação mais detalhada. ${ }^{9}$ Num estudo preliminar, é possível afirmar que o COI-OSS cumpria, também aqui, sua missão de "avaliar a situação 
militar global e os riscos à segurança norte-americana", produzindo subsídios que orientaram efetivamente a atuação diplomática e o planejamento militar dos EUA em relação ao Brasil no período. O próprio recuo de Donovan após a disputa com Rockefeller no que diz respeito a uma ação mais incisiva da OSS na América Latina parece ter sido temporário. Conforme afirma Lochery, após Pearl Harbor: "o espião chefe mandou seus próprios agentes à região, e, portanto, logo se viu envolvido em novas disputas com agências rivais em Washington". ${ }^{10}$

Enquanto isso, o SIS do FBI chegava a contar com 137 agentes nas Américas Central, do Sul e Caribe em 1942, operando em geral disfarçados como funcionários de empresas norte-americanas. No Rio de Janeiro, o SIS possuía um escritório na Avenida Presidente Wilson, supostamente utilizado pelo adido cultural norte-americano. Seus agentes atuavam em íntima parceria com a Delegacia da Ordem Política e Social (DOPS), cujos interrogatórios chegavam a acompanhar, apesar de, na sua versão, "virarem a cara" quando a tortura se tornava mais brutal. O embaixador Jefferson Caffery chegou a indicar ao general Alcides Etchegoyen, que substituiu o filo-germânico Filinto Müller na chefia do DOPS em 1942, a dispensa de "dez pró-nazistas", a serem substituídos por quinze policiais em quem confiava. Rolf Larson, ex-missionário mórmon, ajudou a montar uma polícia política brasileira "nos moldes do FBI", e escolheu para chefiar a missão o delegado chefe da DOPS do Rio Grande do Sul, Plínio Brasil Milano, que realizou um curso na Academia do FBI no início de 1943. A cooperação sofreu um baque quando Milano faleceu misteriosa e precocemente um ano depois em Montevidéu, aos 36 anos de idade, supostamente durante uma "operação de contraespionagem". Ainda assim, Huggins avalia que

O SIS do FBI foi bem sucedido ao infiltrar-se no sistema policial brasileiro. Plantou os fundamentos para que a CIA e o Departamento de Estado internacionalizassem ainda mais a segurança norte-americana depois da Segunda Guerra Mundial. ${ }^{11}$

A intimidade entre FBI e DOPS parece ter rendido frutos já durante a Guerra, conforme pode ser demonstrado no estudo de Hilton sobre o desbaratamento da rede de espionagem da Abwehr (serviço alemão de inteligência militar) no Brasil. ${ }^{12}$

Em matéria de espionagem internacional, porém, os norte-americanos eram novatos, particularmente quando comparados aos seus mestres britânicos. Em junho de 1940, o milionário canadense William Stephenson, veterano dos Royal Flying Corps na Primeira Guerra Mundial, foi encarregado por 
Winston Churchill da montagem de uma rede de espionagem em todo o continente americano, o British Security Coordination-Special Operations Executive (BSC-SOE). Apesar da notória rivalidade entre Hoover e Donovan, Stephenson relata ter trabalhado harmoniosamente com ambos. No outono de 1940, um assistente de Hoover discutiu "o planejamento de uma organização de campo do FBI na América Latina com os cabeças de todas as agências do SIS", e com a equipe de Stephenson. ${ }^{13} \mathrm{O}$ canadense e Donovan, por outro lado, desempenharam papel decisivo para convencer Roosevelt a se somar a Churchill na guerra contra os alemães, e Stephenson cooperou diretamente em todo processo de estruturação da OSS. ${ }^{14}$

No Brasil, o BSC-SOE possuía representação em Porto Alegre, Santos, Rio de Janeiro, Salvador, Recife e Belém. ${ }^{15}$ Stephenson relata em detalhes a falsificação de uma carta que levou o presidente Vargas a suspender o direito da empresa aérea italiana Lati (Linee Aeree Transcontinentali Italiane) voar entre o Brasil e a Europa. Supostamente enviada pelo General Aurélio Liotta, presidente da Lati Roma ao Comandante Vicenzo Coppola, gente da Lati no Brasil, a carta estava repleta de insultos ao presidente e ao país. Mencionava que o "gordinho" (Vargas), estava "no bolso dos americanos", trazia orientações para a articulação e financiamento da tomada do poder pelo "cavaleiro verde" (o líder integralista Plínio Salgado) e concluía dizendo que os brasileiros são uma "nação de macacos que dançam de acordo com quem puxa a corda". A operação para que a carta chegasse ao conhecimento do presidente da República envolveu um assalto forjado à casa de Coppola, e a entrega do documento por um dos supostos "assaltantes" a um repórter da Associated Press. O jornalista a repassou à embaixada norte-americana, e ela foi entregue a Vargas como "descoberta da inteligência norte-americana". ${ }^{16}$

Stephenson reivindica papel de destaque para agentes britânicos em diversos eventos que antecederam à declaração de guerra ao Eixo pelo Brasil, tais como a interceptação de correspondência enviada pelos organizadores do núcleo nazista da companhia têxtil Lundgren, em Pernambuco, a Joseph Goebbels solicitando mais dinheiro e material, que desencadeou uma devassa nas atividades pró-Eixo no estado. Após os suspeitos presos terem sido libertados, relata o canadense, "os agentes do BSC-SOE produziam novas evidências", que tornavam a levá-los para a cadeia, grampeando os seus telefones e violando sua correspondência. Por fim, quando os navios brasileiros foram afundados, os agentes do BSC-SOE teriam participado ativamente das "violentas demonstrações antigermânicas" que se espalharam pelo país "jogando lenha na fogueira". O criador do BSC-SOE relata com satisfação que "em Recife todas as lojas e fábricas alemãs e italianas foram depredadas", noventa e cinco alemães e italianos foram presos e as fábricas dos Lundgren colocadas sob intervenção militar: "em um curto tempo, entre janeiro e agosto de 1942, a organização alemã no Nordeste do Brasil foi quebrada e destruída". ${ }^{17}$ 
Cabe ressaltar que, enquanto no caso da carta da Lati é possível estabelecer uma relação causal mais direta entre a ação da espionagem e os desdobramentos políticos do episódio, a situação de Pernambuco é muito mais complexa. Nas memórias de militantes comunistas atuando no período no movimento estudantil, como o baiano João Falcão, por exemplo, a onda de motins urbanos anti-Eixo teria resultado da combinação entre a comoção espontânea causada pela chegada dos corpos dos tripulantes dos navios afundados à costa nordestina e o trabalho político da militância antifascista por todo o país. ${ }^{18}$ Veremos adiante como, em Belém, os eventos mobilizaram atores políticos de diversos matizes. A gigantesca onda de ações de massas do período em todo país ainda demandará pesquisa mais detalhada. Os detalhes narrados por Stephenson, entretanto, deixam poucas dúvidas de que a inteligência britânica atuou nesses eventos, embora ele provavelmente exagere no peso atribuído a essa atuação no desenrolar dos fatos.

Traçados esses contornos gerais do contexto da espionagem aliada no Brasil durante a Segunda Guerra Mundial e identificadas as particularidades da ação do FBI, da OSS e da inteligência britânica, deslocaremos agora o foco para os Counter Intelligence Corps (Corpos de Contra-inteligência) do Exército norte-americano, aos quais estavam vinculados os agentes cuja atuação em Belém será examinada nas próximas sessões. Os agentes do CIC, recrutados geralmente entre militares com experiência legal, investigativa e domínio de línguas estrangeiras, desempenharam várias tarefas relevantes na Segunda Guerra Mundial. ${ }^{19}$ Uma dessas tarefas, relacionada aos Transportation Corps (Corpos de Transporte), envolvia a avaliação dos riscos à segurança dos portos e aeroportos controlados pelo Exército norte-americano em várias partes do mundo, pelos quais passaram sete milhões de militares e 127 milhões de toneladas de carga, e nos quais trabalhavam 171.000 pessoas.

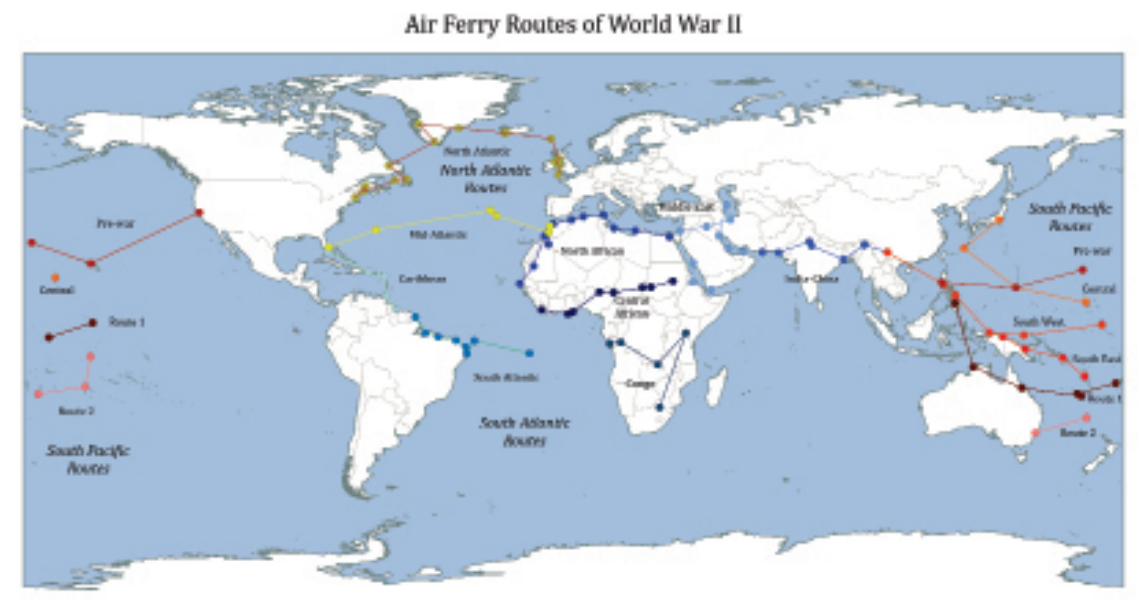

Figura 1: Rotas de transporte aéreo das Forças Armadas norte-americanas na Segunda Guerra Mundial. Fonte: Wikipedia ${ }^{20}$. Destacamos a localização de Belém na South Atlantic Wing. 
Um documento histórico oficial produzido pela escola do CIC em Baltimore em 1951 dedica um capítulo às "Operações no Teatro do Atlântico Sul". Nele, registra-se que os primeiros agentes chegaram ao Brasil precisamente em maio de 1942, ficando vinculados inicialmente ao Air Transport Command (ATC, Comando de Transporte Aéreo) em Recife. O fato do Brasil ainda não ser beligerante, mas já estar "cooperando completamente com os Aliados ao permitir o uso de suas bases para operação contra o inimigo" gerava a necessidade de segredo absoluto a fim de preservar as relações cordiais com o governo brasileiro. ${ }^{21}$ Conforme registra Rebecca Herman, a construção das bases norte-americanas no Brasil foi encomendada pelo Departamento de Guerra dos EUA à Pan American Airways (Panam), empresa privada que operava no país por meio da sua subsidiária Panair. A suposta expansão de aeroportos comerciais foi denominada Airport Development Programa $(\mathrm{ADP})^{22}$. O período entre as declarações de guerra ao Eixo por parte dos norteamericanos (dezembro de 1941) e do Brasil (agosto de 1942) foi caracterizado pela ambiguidade registrada no documento do CIC. As aparências de atividade comercial dos "aeroportos" iam progressivamente cedendo lugar à explicitação do seu caráter de "bases aéreas".

Os agentes retornaram aos EUA em novembro de 1942, mas um novo destacamento foi enviado no início do ano seguinte, ficando vinculado ao quartel-general da United States Air Force Safety Agency (Agência de Segurança da Força Aérea Norte-Americana), novamente em Recife. O trabalho era organizado em três seções. A "contra-sabotagem" observava os "atos e sentimentos dos brasileiros empregados nas bases militares". A "ligação" articulava-se com as agências brasileiras "com o propósito de coordenar o controle e evacuação de civis brasileiros subversivos das instalações militares". Já a "contraespionagem" atuava em roupas civis: "um bocado de tempo era gasto conferindo rumores sobre passaportes roubados ou forjados, e outras estatísticas vitais". O destacamento funcionou até fevereiro de 1944, com seus homens usando uniforme "semi-militar" e se apresentando como "Inspetores do Departamento de Guerra". Um terceiro destacamento passou a operar em 23 de maio de 1944, permanecendo em ação no Brasil até o final da Guerra. Todas as informações sobre "indivíduos suspeitos" eram compartilhadas com "a Polícia Brasileira, os Serviços de Inteligência da Marinha e do Exército Brasileira e o Cônsul Norte-americano", desse modo, segundo o relatório, "o CIC espalhou uma rede ampla, que anulou quaisquer tentativas de ferir o empreendimento bem-sucedido da Guerra". ${ }^{23}$

O panorama traçado até aqui, embora inconclusivo em muitos aspectos, nos ajuda a contextualizar o relato que analisaremos a seguir.

\section{Os agentes}


Em 19 de maio de 1942, os agentes especiais José Maria Bensaude e Anthony R. Mattos foram informados de que seriam transferidos do Counter Intelligence Corps para o United States Ferrying Command (Comando de Transporte de Suprimentos dos Estados Unidos) por um período não superior a seis meses. ${ }^{24}$

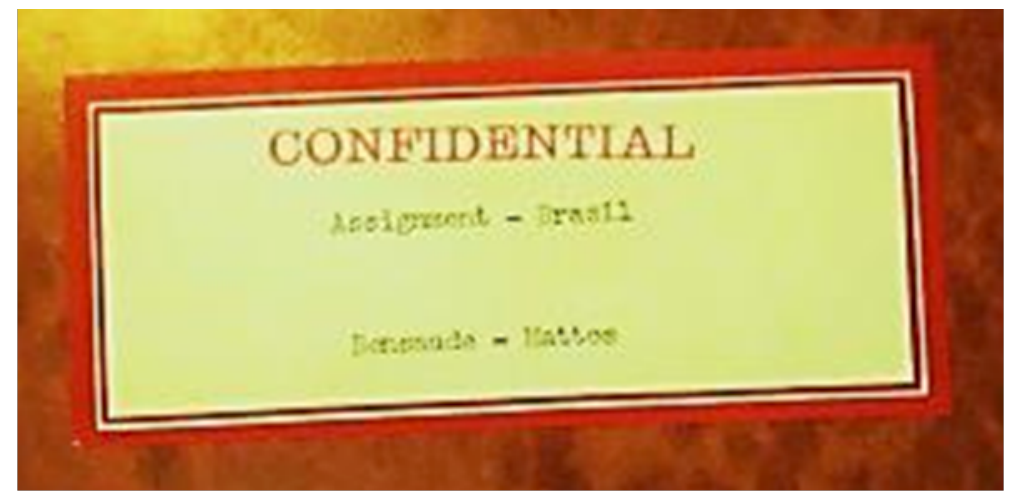

Figura 2: Detalhe da capa do relatório da Missão Bensaude-Mattos. National Archives and Records Administration

O banco de dados do pessoal alistado nas Forças Armadas norteamericanas nos permite obter algumas informações sobre esses personagens. Ambos nasceram em 1917 (tinham, portanto, 25 anos por ocasião da missão), eram identificados como brancos, possuíam quatro anos de ensino médio e eram solteiros, sem dependentes. Bensaude, número de série 12021075, nasceu em Nova Iorque, tinha como atividade civil o "secretariado" e foi incorporado à cavalaria. Mattos, número de série 39010696, nascido em Patterson, Califórnia, ator, foi incorporado ao "ramo imaterial" do Exército. ${ }^{25}$

O obituário de Mattos registra que ele faleceu em 25 de outubro de 2000, aos 82 anos em Cape Coral, Flórida, onde viveu por trinta anos, e fornece informações sobre suas atividades após a missão em Belém. Integrado à $100^{\mathrm{a}}$ Divisão de Infantaria durante a Guerra, lutou na França e na Alemanha. Posteriormente, formou-se em Stanford, obteve grau de mestre e chegou a ser contratado como professor assistente de espanhol na Universidade de British Columbia em 1946. Mas seguiu carreira militar, que culminou, após frequentar as escolas do Comando do Exército e do pessoal das Forças Armadas, com sua promoção a tenente coronel em 1962. Realizou três missões ao Brasil e duas ao Panamá. Foi professor de espanhol na Academia Militar de West Point. ${ }^{26}$

A vida de Bensaude após a Guerra tomou rumo bastante distinto. Ele permaneceu no Brasil, casou com uma brasileira, com quem teve uma filha, e se tornou um homem de negócios, ao que tudo indica representando os interesses da sua milionária família açoriana. Em 25 de janeiro de 1948, o Correio da Manhã noticiava "Um acontecimento festivo na vida comercial do Rio", a criação da "Avipam - Turismo, Pontual Machado - Bensaude, S.A.", tendo 
como presidente honorário Manuel Ferreira Guimarães, acionista majoritário da Panair. A cerimônia foi abençoada pelo Bispo Dom Jorge Marcos de Oliveira por meio da entronização da imagem do Sagrado Coração de Jesus na sala da diretoria, contando ainda com a "presença de altas autoridades civis e militares, banqueiros, industriais, jornalistas e elementos das colônias lusa, norte-americana e francesa". Guimarães, no seu discurso, destacou a importância da participação de Bensaude na empresa,

\footnotetext{
"nome evocativo de gloriosas tradições lusas (...) cujo progenitor vem realizando obra de vulto na América do Norte, país onde a vitória individual tem de ser baseada em demonstrações práticas." ${ }^{27}$
}

Dois anos depois, entretanto, Bensaude se envolveria em fatos mais controvertidos. O jornal A Noite, de 09 de março de 1950 registra sua detenção, ao tentar retirar um Cadillac na Alfândega com documentação falsificada. Apesar da negativa do acusado, o jornal afirma que "a polícia está convencida de que Bensaude chefia a organização" especializada no contrabando de automóveis norte-americanos, dos quais trinta haviam sido apreendidos na ocasião ${ }^{28}$. Três dias depois, o Correio da Manhã saía em sua defesa, classificando como "tempestade em copo d'água" as acusações de envolvimento da "figura conceituadíssima no comércio desta capital", conhecido por sua "conduta ilibada", com a suposta quadrilha de importação ilegal de automóveis. Bensaude alegava ter trazido na bagagem, legalmente, um carro, apenas para "gozar no Brasil um pouco do conforto" de que desfrutava em Nova Iorque, e lembrava as "grandes somas de dinheiro" que investira no país para desenvolver suas "atividades profissionais na indústria e no comércio". ${ }^{29} \mathrm{O}$ episódio parece não ter abalado os negócios do ex-agente. O Diário Oficial da União de 27 de maio de 1950, registra sua escolha como presidente da "Avipam", sediada, coincidentemente ou não, em frente ao atual Consulado (então Embaixada) dos Estados Unidos. ${ }^{30}$ 


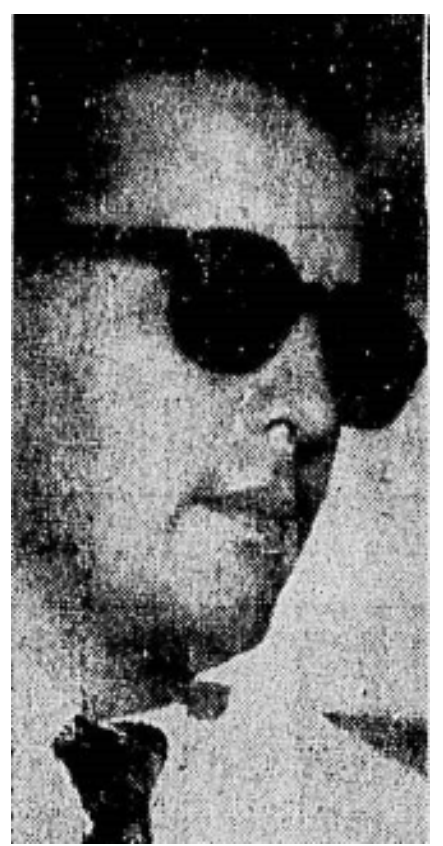

Figura 3: José Maria Bensaude. A Noite, 09 de março de 1950. Hemeroteca Digital da Biblioteca Nacional

O progenitor de José Maria Bensaude, mencionado pelo sócio majoritário da Panair, era José Emile Bensaude (1890-1969), “que emigrou para os Estados Unidos, onde desempenhou papel importante no transporte transatlântico durante a Segunda Guerra Mundial, nomeadamente na criação da Base das Lajes dos Açores". ${ }^{31}$ A biografia do "cientista, pedagogo acadêmico e construtor de violinos" Alfredo Bensaude, pai de José Emile, registra tratar-se de uma família de judeus sefarditas, originalmente denominada "Ha'-Sib-Oni" (Hassiboni), expulsa da Espanha em 1492, que se fixou no Marrocos e migrou para o arquipélago dos Açores em 1818. ${ }^{32} \mathrm{O}$ pai de Alfredo, José Bensaude (1835-1922) fundou a Fábrica de Tabaco Micaelense ${ }^{33}$. Em 1941, a família fundou a primeira empresa aérea portuguesa, a Serviço Açoriano de Transportes Aéreos (SATA) ${ }^{34}$. O banco e a seguradora do Grupo Empresarial Bensaude foram nacionalizados na Revolução dos Cravos, mas eles até hoje constituem a principal força econômica dos Açores. ${ }^{35}$

A expansão das atividades econômicas dos Bensaude do ramo agroindustrial para o da aviação e turismo deu-se, portanto, precisamente no contexto da Segunda Guerra Mundial, e passou por forte envolvimento com negociações diplomáticas e com operações da inteligência norte-americana. $\mathrm{O}$ acervo da OSS depositado no National Archive and Records Administration contém "registros relativos a Jose Bensaude e à compra do S.S. Olivia para viagens entre os Estados Unidos e as Ilhas de Cabo Verde, cerca de abril de 1942 a 1943", período que, diga-se de passagem abarca os meses que o jovem José Maria Bensaude passou em Belém. ${ }^{36}$ Os microfilmes produzidos pelo general 
Donovan a partir de "documentos selecionados" quando a OSS foi extinta, em 1945, também mencionam o "Projeto Olivia". ${ }^{37}$ Alexandre Luis Moreli Rocha, na sua tese sobre o papel estratégico do arquipélago do Açores entre a Segunda Guerra Mundial e a Guerra Fria, menciona memorandos de julho de 1943 nos quais o subsecretário de Estado Adolf Berle Jr. apoia a iniciativa da empresa norte-americana TWA de associar-se aos Bensaude na criação de uma companhia aérea portuguesa (a atual SATA). ${ }^{38}$

Portanto, unidos pela sua condição geracional e pela capacitação linguística para atuarem como membros do CIC, as trajetórias posteriores e o contexto social de Mattos e Bensaude levaram a desdobramentos bastante distintos de sua missão no Brasil durante a Segunda Guerra Mundial. Para o primeiro, tratou-se de um importante passo para uma carreira militar com vinculações acadêmicas. Para o segundo, de um elo numa complexa cadeia de negócios internacionais de uma família que soube explorar sua condição como força econômica dominante em uma posição geográfica estratégica para estabelecer-se em um novo e promissor ramo de atuação.

\section{A missão}

Em 21 de maio de 1942 Bensaude e Mattos foram informados pelo capitão Rudolph Morgan, de que iriam a Belém em missão cujos detalhes ainda desconheciam, enquanto Morgan seguia para Natal, acompanhado do agente especial T. M. L. Wright. ${ }^{39}$ Em Belém, os agentes ficariam clandestinos junto aos soldados da base aérea norte-americana por duas a três semanas aguardando ordens mais específicas. Chegaram ao destino no dia 26, juntamente com três operadores de rádio e um mecânico. As instruções, inicialmente, foram para registrar mentalmente a maior quantidade possível de informações sobre a cidade e a base.

Apresentaram-se ao tenente coronel Cairns, comandante da base, que estava informado sobre o seu status de agentes, e em $1^{\circ}$ de junho foram nomeados como encarregado da Polícia Militar (Bensaude) e como sargento de transportes (Mattos). Inicia-se aí um longo conflito, descrito de forma recorrente nos relatórios produzidos por ambos, entre as atribuições que lhes foram atribuídas como soldados comuns (o disfarce sob o qual se ocultavam) e suas tarefas "de inteligência", que não conseguiam cumprir adequadamente em função das primeiras.

Bensaude foi encarregado de dirigir junto com dois outros militares por Belém das cinco da tarde à meia-noite, patrulhando lugares frequentados por soldados norte-americanos, especificamente em torno do Grande Hotel, do Teatro Olympia e do Distrito da Luz Vermelha. A ronda passava também pela "Estação Profilática", instalação na qual os soldados americanos que mantivessem relações sexuais na cidade eram obrigados a passar para receber medicação, sob pena de corte marcial caso viessem a ficar doentes tendo 
negligenciado o procedimento. ${ }^{40} \mathrm{~A}$ responsabilidade da patrulha era "garantir a ordem e disciplina militar nas visitas dos soldados à cidade". O trabalho de Bensaude, porém, não se resumia a isso. Ele dava aulas diárias de português para os soldados, fazia a tradução de correspondência, servia de intérprete para o comandante, seu auxiliar e o médico da base, fazia compras de suprimentos e liberava cargas nas docas da SNAPP (Serviço de Navegação na Amazônia e Administração do Porto do Pará). Mattos, além de administrar o uso, abastecimento de combustível e manutenção de doze veículos, chefiando nove motoristas e ainda cuidava do pagamento de fornecedores do refeitório. Em um de seus primeiros relatórios a Morgan, ambos se queixam que, em muitas ocasiões, foram solicitados a:
"comprar certo tipo de graxa de sapato, certo tipo de escova de dentes, e de pasta de dentes, assim como certos souvenires, levar camisas para serem consertadas em certos alfaiates, solicitar que meias-solas fossem colocadas de certa maneira nas solas de certos oficiais, levar fotos para serem processadas em certa loja de material fotográfico e buscá-las quando ficassem prontas."

Ainda assim, os agentes levantaram, rapidamente, um volume considerável de informações sobre as unidades militares brasileiras na região. O Exército possuía o $34^{\circ}$ Batalhão de Caçadores, em Val-de-Cans ${ }^{41}$, perto da base aérea norte-americana, o $26^{\circ}$ Batalhão de Caçadores, onde funcionava o quartel-general e o Batalhão de Artilharia. Havia 2.000 soldados em Belém, "na grande maioria dos casos, transferidos de Rio e São Paulo nos últimos meses". O brigadeiro Savaget, chefiava a $1^{\mathrm{a}}$ Divisão Aérea, localizada próxima ao escritório do consulado norte-americano, que possuía um centro de treinamento para aviadores recrutados atrás da base aérea. Os agentes verificaram que os aviões da FAB eram Funks, Taylorcrafts e Cubs, e foram informados de que o Brasil receberia mais "bombardeiros e aviões americanos para treinamento" e que em breve começaria a "produzir seus próprios aviões no Rio".

Em visita ao $34^{\circ} \mathrm{BC}$, Bensaude e Matos registraram detalhadamente a rotina do recruta brasileiro. Ele acordava às cinco da manha, tomava "um banho obrigatório", limpava o seu alojamento, fazia "um desjejum leve de café com um pequeno pedaço de pão", tinha um período rápido para lustrar o equipamento, seguido por duas horas e meia de exercícios físicos. Após dez minutos de descanso, às nove e dez os soldados retornavam ao quartel, se limpavam e almoçavam, "usualmente macarrão e almôndegas". As atividades eram retomadas à uma e meia da tarde, com aulas de "estratégia militar e disciplina", encerrando-se o dia de trabalho às quatro da tarde. Ganhando apenas 21 mil réis por mês, os recrutas tinham uma "vida social extremamente limitada": 
"A maioria deles parece ter sido de classe baixa na sua vida civil - trabalhadores, camponeses. Porém, o treinamento pelo qual passam como recrutas os torna soldados eficientes, de boas maneiras e muito corteses. [...] Estes agentes notaram que o relacionamento entre o soldado americano e o soldado brasileiro é de alto nível e que a melhor cooperação e amizade existe entre ambos o tempo todo."

Os agentes observaram também diversas questões referentes à infraestrutura e a questões de abastecimento da cidade. Destacaram por exemplo que os armazéns da SNAPP eram "de vital importância para Belém e outras cidade do Rio Pará", e que havia guardas civis postados no local, mas "descuidados", sendo que "qualquer um com habilidade pode entrar e sair sem ser notado". Assinalaram que o Ferrying Command recebia suprimentos, unidades de transporte e material médico pelo armazém 7, e que todos os navios que entravam nas docas eram registrados pelo Escritório do Inspetor Marítimo, com informações sobre hora, carga, número e nome de passageiros, destino, etc. Chamaram a atenção para um estabelecimento estratégico da SNAPP em Miramar, no qual se localizavam os tanques de gasolina e óleo da Texaco e Standard Oil e um grande píer onde os combustíveis eram descarregados pelos navios. Comentaram também sobre o açougue localizado em Pinheiro, a doze milhas de Belém. Financiado pela prefeitura, funcionava sem refrigeração, e a carne abatida tinha que ser consumida no dia seguinte. O relatório mencionava ainda a ferrovia destinada a transporte de carga para Santa Isabel e Bragança, com 240 quilômetros, com locomotivas antigas movidas a carvão. A Companhia de Força Elétrica, perto das docas, acessada por meio de um bonde, possuía estrutura antiga de zinco galvanizado e tinha um maquinário eficiente, apesar de "furos por toda parte", com uma "aparência pobre", e acesso fácil, sendo protegida apenas por dois guardas. Já companhia de águas possuía um tanque de aço em São Braz, de 50 a 75 pés de altura sendo a água bombeada de um poço abaixo. Um fato preocupante, na visão dos agentes, era que "fotografias de aviões, jipes, prédios, instalações, caminhões do Exército americano estão sendo levados para revelar na Fotografia Alemã, de propriedade de judeus alemães".

Quando o Capitão Morgan finalmente chegou a Belém, em 8 de julho de 1942, a missão dos dois agentes foi explicitada e começou a dar resultados mais concretos. As informações sobre tipos suspeitos e instalações estratégicas passaram a ser utilizadas para a produção de um plano de defesa da base aérea, pois, como resumiram num memorando na semana seguinte: 
"Um ataque ao aeroporto de Val-de-Cans é possível com o possível objetivo de sua utilização como um último degrau em direção ao Canal do Panamá, ou com o objetivo de acabar com as instalações existentes, impedindo o uso dessas instalações por parte dos aviões brasileiros e norteamericanos."

Morgan aceitou o argumento de que as mil e uma "tarefas obsoletas" dadas aos agentes os impediam de agir contra os "inimigos muito ativos na área". Descreveu dificuldades similares em Natal, mas explicou que o deslocamento dos agentes para outro local ou a decisão de que atuassem "em roupas civis com liberdade de ação" não seriam imediatas. Concordou que alugassem um quarto na cidade para escreverem relatórios e guardarem material. Nessa nova etapa dos trabalhos, Bensaude e Mattos fizeram contato cm o "escritório do G-II" (inteligência militar) na cidade para obter a indicação de cinco informantes, dos quais foi demandado o pagamento de duzentos milréis "como garantia".

No dia 10 de julho, ambos atuam como intérpretes numa reunião entre o comandante Cairns, o general Euclydes Zenóbio da Costa ${ }^{42}$, comandante da $8^{\text {a }}$ Região Militar, e seu auxiliar, tenente coronel Aguinaldo Caiado de Castro $^{43}$, dois oficiais brasileiros que, após treinamentos nos EUA, viriam a ter papel de destaque na Força Expedicionária Brasileira, assim como no segundo governo Vargas. Foram analisados mapas detalhados da base e da periferia de Belém, usados para a definição da localização de baterias antiaéreas, faróis e aparelhos de escuta. Costa explicou que o planejamento de defesa da base fora aprovado no Rio de Janeiro, mas que os equipamentos solicitados aos EUA ainda não haviam sido recebidos. Isso incluía botes Mosquito e aviões de busca necessários para patrulhar fronteira com Guiana Francesa, os afluentes dos rios Amazonas e Pará, além da parte sul da costa Atlântica do Pará, onde submarinos tinham sido avistados. Três unidades de artilharia costeira seriam criadas, de tamanho e localização a depender das observações feitas com os botes. Até então, explicou o general, apesar de unidades de Artilharia de Campo serem amplamente disponíveis em toda área, não havia nenhuma espécie de defesa antiaérea, e o único armamento disponível para essa finalidade eram metralhadoras calibre 50 em suportes especiais, com alcance máximo de 1.000 metros, sendo, portanto, pouco efetivas. ${ }^{44}$

Ficou acertado que, de imediato, o Exército americano contribuiria com mais metralhadoras calibre 50 refrigeradas a água, três rifles Garand e duas metralhadoras B-17 de cano duplo. O Exército brasileiro forneceria os demais homens e equipamentos necessários. A primeira parte do plano seria instalação de três metralhadoras. Uma delas, perto de Val-de-Cans, protegendo a torre de controle, o hangar da Panair, a estação de rádio, o depósito de combustível e as operações. As demais ficariam perto do quartel e hangar norte-americano e 
no quartel do $34^{\circ}$. Todas entrariam em ação dois minutos após um alarme ser acionado. A segunda parte do plano envolvia a ampliação do armamento em torno do campo operado pelo Exército Brasileiro, visando proteger as aeronaves em solo, e entraria em ação 15 minutos após o alarme soar. O plano incluía ainda a organização e treinamento de "elementos de choque (...) para atacar tropas de paraquedistas ou unidades que possam tentar pousar no campo".

Bensaude e Mattos deram outra contribuição decisiva à segurança da base aérea, ao sistematizarem as "orientações a oficiais em trânsito". Elas começavam com a denominação e localização do campo, indicando que a cidade possuía cerca de 300.000 habitantes. Explicavam os procedimentos de contato com torre de controle, o serviço de aterrissagem operado pela Panair, a necessidade de taxeamento a um local afastado e de que um tripulante ficasse junto cada aeronave durante a noite. Indicavam que bens, com papéis confidenciais e códigos deveriam ser guardados num cofre. Não havia acomodações específicas para oficiais, que poderiam ficar no alojamento coletivo pagando cinquenta centavos de dólar por noite, com "banheiros escassos", ou optar pelo Grande Hotel (três dólares sem banho, quatro com banho, em ambos casos com refeições incluídas). Na base, café da manhã, almoço, sanduíches ou frutas fora de hora estavam disponíveis por 35 centavos de dólar, jantar por quarenta. O transporte entre o campo e os aviões era garantido, mas para cidade estava restrito aos lá hospedados.

A prevenção à malária passava pelo uso de redes para mosquito e, caso contraída a doença, o tratamento com quinino deveria ser iniciado apenas após sete dias. Vegetais crus não deveriam ser consumidos, e apenas água engarrafada, "como a Maguary" deveria ser utilizada. Alertava-se sobre a "alta taxa de doenças venéreas no Distrito da Luz Vermelha", indicando-se que a estação profilática era "operada pelo departamento médico das 6 da tarde às 11:30" e que sua localização poderia ser obtida "com a Polícia Militar [da base norteamericana]". Acima de tudo, era fundamental manter a discrição:

"NÃO FALE. Lembre-se que o Brasil é um país neutro, e é fato sabido que agentes inimigos operam aqui. Por que contar a eles onde você está indo e o que está fazendo? Pode custar a sua vida e a vida de outros."

O documento ainda elencava informações sobre taxa de câmbio, sobre o envio de cartas, que seriam censuradas pelos oficiais e não deveriam fazer menção à localização, origem ou destino, sobre os procedimentos de autorização para partida de aeronaves. O comportamento dos soldados 
americanos em Belém era considerado fundamental para a conquista da simpatia da população local:

\begin{abstract}
"Seja particularmente cuidadoso em relação à sua roupa e comportamento na cidade. Os brasileiros julgam os Estados Unidos pelos americanos que eles veem na cidade e, devido à delicada situação internacional, é altamente desejável que nós criemos uma boa impressão. Gravatas são usadas em Belém."
\end{abstract}

Esse seria o foco de uma nova comitiva de oficiais norte-americanos que chegaria à cidade em 16 de julho, incluindo os coronéis Henry, Mosley e Hood (Escritório do Advogado Geral do Júri, Washington). Os militares se reuniram com o Dr. Miguel Martins (inspetor de Saúde dos Portos) ${ }^{45}$, buscando um "entendimento mais estreito" sobre a presença dos soldados americanos em Belém. Martins sugeriu que "jogos de bola deveriam ser organizados entre soldados americanos e brasileiros", com renda revertida para caridade. Criticou os soldados americanos por ficarem "à vontade demais quando circulam no entorno do Grande Hotel", mostrando desleixo ao "colocar os pés sobre outra cadeira":

\footnotetext{
"quando os soldados americanos assistem a um filme nas noites de domingo, quando todas as famílias brasileiras decentes estão no público, eles se refestelam demais no lobby e sentam no cinema de uma maneira não-militar, fazendo às vezes um bocado de barulho desnecessário."
}

Martins acrescentou, não ver razão "para as tropas americanas não terem camisas e calças extra para parecerem mais arrumados no uniforme aos domingos ou para uso em ocasiões especiais”. Essa percepção, entretanto, não era compartilhada pelo prefeito Abelardo Conduru e pelo governador do estado, José Malcher, nem mesmo pelos comandantes militares brasileiros, Castro e Costa, que enfatizaram, ao contrário, a "grande amizade" existente entre soldados americanos e brasileiros. ${ }^{46}$

De todo modo, prevaleceu a avaliação de que era necessário adotar maior rigor em todos os aspectos, e em 17 de julho:

"O oficial comandante de Val-de-Cans recebeu centenas 
cópias mimeografadas sobre as roupas e o comportamento de oficiais e homens alistados em trânsito. AOrdem Especial para os oficiais em trânsito estabelece que qualquer oficial pode visitar Belém ao chegar aqui apenas se propriamente vestido, com gravata e uniforme limpo; que os oficiais não devem discutir com ninguém exceto pessoal autorizado sobre tipos de avião em que estão, origem do voo, destino, paradas do voo, quantidade de homens a bordo, quantidade de equipamento, e tipo de equipamento a bordo ou qualquer instalação de campo. A Ordem Especial para os homens alistados é a mesma que acima, exceto que homens alistados parando apenas por uma noite estão restritos ao aeroporto de Val-de-Cans até partirem na manhã seguinte"

Por fim, após ajudarem a elaborar o plano de defesa da base e prepararem as orientações para militares americanos em trânsito, os agentes retornaram a Washington e, em novembro de 1942, elaboraram recomendações para a atuação do CIC no Brasil.

As novas missões teriam "completa liberdade de operação", com vínculo administrativo à ATC em Recife, estabelecendo-se escritórios em outras áreas do país quando necessário. Os agentes não deveriam ser utilizados para outras tarefas, como ocorrera com ambos em Belém e estariam habilitados a usar suas credenciais diretamente com outras agências do governo americano no Brasil. Os escritórios trocariam relatórios periódicos, solicitando eventualmente o pessoal dos outros para missões específicas. Antes de vir ao Brasil, todo material do FBI, Office of Naval Intelligence (ONI) e Military Intelligence Service (MIS) sobre o país (literatura subversiva, surveys de cidades, etc.) seria fornecido aos novos agentes. Após sua instalação, eles enviariam relatórios periódicos a esses órgãos. Na preparação das missões, seriam também utilizadas as instalações da Biblioteca do Congresso para o estudo da situação econômica do Brasil e as relações internacionais do país, incluindo "conexões de negócios que existem há anos antes da irrupção da guerra". O Departamento de Comércio deveria lhes fornecer "listas de comerciantes de várias mercadorias", e eles precisariam conhecer as indústrias militares brasileiras. Para operar adequadamente, necessitariam ainda da cooperação de bancos, "preferencialmente do próprio Banco do Brasil". As recomendações de Bensaude e Mattos se encerram com uma cronologia histórica geral do país e dados de 1937 sobre a quantidade de imigrantes de cada nacionalidade estrangeira. Destacam que desde 1825 havia "alemães no Brasil, onde ajudaram a desenvolver os negócios de café e borracha". Por fim, indicam os tópicos de estudo necessários à preparação de qualquer agente que viesse a atuar no país: "o povo que habita o Brasil", "a história do país", "o governo do país", "educação e religião", "agricultura", "geografia", "transporte e comunicações", "as Forças Armadas", "a influência 
do Eixo, seu método de operação, etc".

Tipos suspeitos

Nos seis meses que permaneceram na Belém, Bensaude e Mattos descreveram uma vasta galeria de personagens e os ambientes em que eles circulavam, compondo um interessante panorama do cotidiano da vida social local. Em 30 de junho de 1942, ambos solicitaram um passe noturno, alugaram um quarto de hotel e uma máquina de escrever com dinheiro próprio e passaram a redigir seu primeiro relatório, traçando um quadro da interação entre os militares norte-americanos e a cidade:

\begin{abstract}
"O centro da atividade social durante o dia e a noite é sem dúvida, o interior e os arredores do Grande Hotel, onde soldados americanos e transeuntes brasileiros, assim como oficiais brasileiros e civis se juntam e discutem eventos, seja na mesa de jantar, no pátio ou enquanto passeiam por perto. Estes Agentes observaram em diversas ocasiões discussões sobre movimentos de aviões e de tropas, suprimentos, equipamentos de rádio, estações de rádio, localização e frequência das mesmas, conhecimento dos deveres de patrulhas, fotografia aérea, partida e chegada de navios a vapor, o destino do pessoal militar norte-americano, para onde estão indo e de onde estão vindo, número e integrantes de determinadas missões, tipos de missão, conhecimento técnico sobre as instalações e o pessoal em Val-de-Cans, Belém, Natal e Recife, também são frequentemente comentados por homens do ADP (Airport Development Program), americanos residentes na cidade, assim como brasileiros nativos e 'ditos' brasileiros"
\end{abstract}

A polícia mantinha um informante disfarçado permanentemente no Veneza Bar, na Praça da República, palco de jogo de biliar frequentado por civis, na maioria pró-Eixo. No vizinho Hotel Central, que atendia "às pessoas de melhor classe" ocorriam encontros pró-Eixo entre habitantes locais e visitantes. Já na Pensão Americana, metade dos quartos eram alugados para sargentos da Marinha brasileira, desejosos por local para onde pudessem levar "garotas diferentes daquelas do Distrito da Luz Vermelha". Na opinião dos agentes, vários "tipos suspeitos" estariam se aproveitando das conversas "casuais" nesses locais para obter informações. O senhor "Brasinha", inspetor de polícia, solicitado a ajudá-los com dados sobre esses indivíduos revelou que já trabalhava clandestinamente na base aérea para a Panair com a mesma finalidade.

A lista de "suspeitos" foi se tornando longa. Um francês hospedado no 
Grande Hotel, quarto 83, havia seis meses, dava nomes diferentes e versões variadas sobre seus negócios. Havia rumores de que se tratava da "ovelha negra de uma família respeitável". Manuel N. Souza, Inspetor de Imigração, natural de São Paulo, vivia há anos em Belém, era "100\% integralista" e mantinha contato com soldados norte-americanos. Alfredo Mattos, 45 anos de idade, trabalhando para a Ferreira Pinto e Cia, agentes de refrigeração, considerado pró-nazi, pagou as contas de vários alemães que haviam se hospedado no Grande Hotel. O oficial subcomandante do $34^{\circ} \mathrm{BC}$, capitão Tasso, falava fluentemente português, espanhol, francês, alemão, além de um pouco de inglês. Dizia "não gostar do povo alemão, mas apreciar a língua". O sírio John Homsi, "amigo dos soldados americanos" sustentava que " $50 \%$ das Forças Armadas brasileiras são definitivamente pró-Eixo", dizia não ser político, mas sabia demais sobre tudo. Homsi costumava ser visto com o tenente Siqueira, que teria recebido treinamento na cavalaria Alemã. Siqueira, de São Paulo, mas com parentes em Belém, fez uma "observação anti-britânica e antiamericana" num banquete oferecido pelo seu "primo rico", o diretor fiscal, sendo ameaçado de agressão por um empregado do Banco Ultramarino. O diretor do banco promoveu um aperto de mãos selando a paz entre os dois.

Antonio Carvalho Nina, 19 anos, trabalhou para Panair, foi demitido após ser pego fumando perto de tonel de gasolina, seguiu para o Amapá, mas retornou a Belém, onde circulava com os marines. Ele e o stamp boy Cavalcante vendiam perfumes que obtinham no "Santo Domingo", navio que viajava entre Belém e a Guiana Francesa. O contrabando de perfumes gerou suspeitas maiores quando um submarino foi visto a 90 milhas da foz do rio Pará, no dia 16 de julho. O capitão Rambo, que esperava no Grande Hotel o reparo do seu anfíbio para retornar a Manaus comprou "perfume francês caro" na Casa Benchimol. Ao perceber a existência de um grande estoque, imaginou que a mercadoria estava sendo obtida em "troca com submarinos inimigos". Excitado, comentou com o assunto com o sargento Boylon, observador Naval do Vice-consulado norte-americano, que discordou da teoria mas, na dúvida, enviou Bensaude e Mattos à casa de comércio para avaliarem a situação.

A passagem de um suposto agente alemão pela cidade mobilizou os agentes. A 7 de agosto eles foram informados pelo capitão George Tiffany, marechal diretor de Val-de-Cans, que o sr. MacNeil da Standard Oil Company tinha sido solicitado pelo capitão Morgan a identificar o cidadão Hans Meyer a esses agentes para "qualquer ação que julgassem necessária". Meyer, em Natal, se associara tanto a soldados americanos quanto a simpatizantes do Eixo. Seguira para Belém de barco, pois a passagem aérea lhe foi negada em função da sua nacionalidade. Ao chegar, dois dias depois, hospedou-se como turista no Hotel Central, e foi mantido sob observação. Na primeira noite, passou duas horas com um amigo, com quem conversava em português fluente, na "Pensão Zezé", onde "leu a mão de uma prostituta chamada Louisa, mas não foi para 
o quarto com ela". Seguiram depois para a "Pensão Crystal", onde Meyer "se associou com a prostituta Dorquinha" e bebeu cerveja. No dia seguinte, os agentes o observaram no saguão do hotel, no correio e no escritório da empresa ITA, onde comprou passagem de primeira classe para partir às onze da noite para a Bahia, a bordo do SS Itavagé. Pegando o mesmo táxi utilizado pelo alemão, os agentes descobriram que ele fora à Rua $1^{\circ}$ de Maio 803, residência de José Lourenço. Meyer retornou a Belém de 18 a 28 de agosto, registrandose como "senhor Lehmann", de "nacionalidade Flamenga". Ele "ficou íntimo dos funcionários do hotel", mas "não saiu do quarto nas 24 horas após o Brasil ter declarado Estado de Beligerância".

Americanos residentes ou de passagem por Belém também geravam preocupações. O senhor e a senhora Allen, "norte-americanos residentes em Belém, cabelo vermelho, sardas, 35 anos, nariz proeminente, socializam com tropas americanas, mas são anti-britânicos". O sargento Boyton, que permaneceu uma semana na cidade, bebia pesado e agia de forma indiscreta, assim como o Tenente Peters, que dizia ser "homem do Seviço de Inteligência Militar (MIS)", mas discutia abertamente sua missão na África. O senhor Halem, repórter do Chicago News, ficou surpreso pelo fato de Bensaude e Mattos falarem português e indagou com desconfiança sobre suas atribuições. Ele andara pela cidade levantando dados sobre a base, e o capitão Tiffany reuniu-se com o cônsul para alertá-lo que deveriam evitar a publicação do trabalho do jornalista. Os agentes assim o descreveram: "35 anos, óculos grossos, personalidade desagradável, muito direto".

Os agentes mantiveram um relacionamento estreito com o engenheiro A. Bibiano, ao qual revelaram sua condição em 21 de julho. Proprietário e operador de uma fábrica de borracha no Rio Amazonas, a 150 milhas de Belém, Bibiano vivia na capital havia seis anos, lidando com banqueiros, fornecedores, companhias de navegação e negociantes de borracha. Morava com a esposa no Hotel Avenida e era estimado nos círculos sociais e empresariais. Residira na Inglaterra por cinco anos, passara tempo em Portugal, falava francês e inglês. $\mathrm{O}$ engenheiro dizia que as pessoas comuns no Brasil tinham sido muito influenciadas pelo sistema alemão de propaganda. Exemplificava relatando que máquinas de escrever similares às britânicas e americanas, vendidas a um conto e quatrocentos mil-réis, eram fornecidas pelos alemães por duzentos mil-réis. No seu interior, havia panfletos dizendo que os fabricantes alemães abriam mão do lucro "porque queriam que os brasileiros tivessem acesso a esses luxos". O mesmo sistema, dizia, tinha sido aplicado a "refrigeradores, automóveis e rádios". Os alemães também tinham estabelecido transmissões de ondas curtas para o Brasil antes dos britânicos e americanos. Bibiano dizia que, no momento, o regime de Vargas acreditava que "boas relações com os Estados Unidos são indispensáveis e essenciais para o desenvolvimento futuro e para o rápido progresso industrial do Brasil". Mas lembrava que o governo alemão 
tinha "altos oficiais por toda parte sul do Brasil" e, que apesar da ação recente contra eles, sua influência em círculos militares e governamentais persistia. Havia, no seu entender, uma "alta percentagem de simpatizantes pró-alemães em todas as seções do Exército brasileiro", que, entretanto, iria "desaparecer quando a Alemanha começasse a se desintegrar".

Quando a esposa de Bibiano viajou para o Rio para negociar a venda de uma casa, ele lhes revelou novas informações sobre sua vida. Trabalhara para a Bentz Motors na Alemanha por dois anos, fora casado com uma alemã de quem se divorciara no Uruguai antes de casar com a atual esposa, brasileira. Os agentes começaram a estranhar, entretanto, suas perguntas "sobre aviões americanos, causas principais para aterrissagem forçada, principais diferenças em funções de carburadores em aviões enviados para temperaturas altas ou baixas". Perceberam que ele lançava questões sobre a força das defesas americanas em Val-de-Cans, enquanto culpava os Estados Unidos por "falharem em cooperar com o Brasil nos negócios de borracha e castanha antes da guerra começar." Atentando para o seu modus operandi, passaram a suspeitar dele:

"O cidadão nunca se comprometeu a dizer que é $100 \%$ aliado; mas usa o seu charme para entusiasmar o ouvinte, e então pergunta 'a queima-roupa' questões diretas e abertas para pegar o ouvinte fora de equilíbrio, ganhando assim informações valiosas. Esses agentes acreditam que o método de abordagem e as questões perguntadas por Bibiano não são apenas a curiosidade de um leigo, mas que há um propósito definido por trás de sua abordagem metódica e bem planejada."

O contato com Bibiano foi encerrado após a declaração de guerra, quando ele os procurou, angustiado. Sendo oficial da reserva, poderia ser convocado, e decidiu ir ao Rio se apresentar antecipadamente. Estava desgostoso, pois "justamente quando o negócio de borracha estava se tornando próspero, a guerra tinha irrompido".

Após o retorno de Bensaude a Washington, Mattos foi orientado a investigar rumores sobre Salinas, no litoral paraense. Viajando em roupas civis pela ferrovia de Bragança por $240 \mathrm{~km}$, chegou à Vila de Capanema, com 3000 habitantes. Após $72 \mathrm{~km}$ de "estrada pobre", alcançou o destino, num trajeto total de 10 horas. Lá verificou que um pescador chamado Tito tinha um barco grande e pescava tubarões, de cujo fígado era extraído óleo, vendido por um certo Frederico, e "usado em motores a Diesel com excelentes resultados". Mattos alugou um barco e viajou até a fábrica de cal deserta pertencente a Francisco, na qual encontrou várias salas vazias, "mas numa delas havia seis galões de 100 litros com óleo e um galão com 25 a 30 libras de fígado fresco". 
Como esse óleo não estava à venda em Belém, o agente concluiu que ele sendo "embarcado em Salinas e levado em barcos à frota submarina do Eixo" que estava "à espreita nessas costas". Pouco tempo depois, o chefe de operação telegráfica que vivera em Salinas por dez anos, foi levado em custódia "por transmitir códigos secretos ao Eixo".

$\mathrm{O}$ foco da preocupação dos norte-americanos, entretanto, dirigia-se cada vez mais à colônia nipônica. A 16 de agosto, os agentes fizeram investigações sobre os japoneses residentes perto do aeroporto. Localizaram três casas de madeira com telhado de folha de bananeira, habitadas por cerca de nove ou dez pessoas, entre cidadãos japoneses e descendentes. As condições de vida eram "de padrão muito baixo". Cada família, com 15 a 20 acres de terreno, plantava alface, couve-flor, cebola, tomate e outros tipos de vegetais. A terra era fertilizada e irrigada constantemente. Às cinco e meia da manhã, os japoneses podiam ser vistos levando verduras para o mercado em carros-de-mão de madeira. A casa localizada "no número 211 da Estada da Rodagem" tinha seis empregados brasileiros. O dono fora preso três meses antes. Segundo vizinhos, a família chegara do Japão dois anos antes e só falava japonês. Outras duas famílias residindo próximas a uma fábrica de tijolos eram compostas por "cidadãos brasileiros":

\begin{abstract}
"O dono também está na cadeia e é visitado frequentemente pela esposa, que é uma mulher idosa, uma filha de 18 anos e três meninos, entre 15 e 20 anos de idade. A família inteira fala português fluentemente. Um dos meninos, chamado Ruy, informou estes agentes que ele é brasileiro de nascimento, que ele nasceu no Alto Amazonas e veio para Belém 12 anos atrás. Ruy tem cerca de 20 anos de idade e é tipicamente um japonês. Ruy acrescentou a estes agentes que ele não fala japonês fluentemente, mas que pode entender bem. Os vizinhos disseram que há um total de doze japoneses homens de 16 a 22 anos de idade e 25 mulheres de todas as idades na vizinhança, e que os pais das famílias estão na prisão (...) a família de Ruy foi muito simpática e convidou estes agentes a retornar no futuro" (ênfase acrescentada).
\end{abstract}

Infelizmente, a simpatia não foi retribuída. Após o afundamento de navios brasileiros pelos submarinos do Eixo, o Estado brasileiro, as massas populares e os militares norte-americanos não trataram Ruy e os seus familiares como "cidadãos brasileiros", mas sim como "tipicamente japoneses". As informações detalhadas obtidas pelos agentes da inteligência militar norteamericana sobre as colônias japonesas foram provavelmente utilizadas para planejar o confinamento dos japoneses e nipo-brasileiros paraenses no Campo 
de Concentração de Tomé-Açu. ${ }^{47}$

\section{A erupção do nacionalismo de massas}

A estada dos agentes do CIC em Belém coincidiu com o desencadeamento de mobilizações de massas anti-Eixo que transformaram as multidões urbanas em protagonistas do processo político do país. Na manhã de terça-feira, 18 de agosto de 1942, após diversas embarcações serem afundadas pelo submarino alemão $U-507$ na costa brasileira, resultando em 551 mortes, circulavam em Belém rumores de que

\footnotetext{
"a população civil desta cidade estava organizando um encontro de massas com o objetivo final de destruição das assim chamadas firmas e residências alemãs, italianas e japonesas nesta cidade e para capturar em custódia os assim chamados comerciantes e Agentes do Eixo"
}

Chegando à Praça do Relógio às 11 da manhã, encontraram "algo entre três a cinco mil pessoas", que identificaram como "estudantes e comerciantes da cidade e das áreas em torno", todos "altamente entusiasmados e unificados em princípios, começaram a gritar e cantar o hino nacional de forma interminável". Diversos oradores "subiram aos pés do grande relógio situado ao centro da Praça Marquês de Pombal" denunciando as "barbaridades e atrocidades das potências do Eixo”. O presidente do Centro Pan Americano, Dr. Mário Chermont ${ }^{48}$, "apresentou às massas um claro e conciso retrato da atividade do Eixo contra mulheres e crianças inocentes a bordo nos navios brasileiros" e enfatizou "que o tempo tinha chegado para ação - ação imediata - contra a traição e a covardia". Discursaram também o padre Davino Ferreira ${ }^{49}$, o doutor Osvaldo Viana, o estudante Aloisio Chaves ${ }^{50}$ e o Professor Leonidas Monte.

Às 11:45, os manifestantes se dirigiram "aos escritórios dos jornais da cidade, expressando a necessidade de completa unificação entre eles e o povo brasileiro na campanha contra o vandalismo do Eixo". Paralelamente,

"grupos mais excitados não interessados em escutar mais discussão e oratória, atacaram e saquearam casas comerciais e residência de estrangeiros alemães, italianos e japoneses suspeitos. Grupos similares por toda municipalidade de Belém, incluindo Pinheiro, Mosqueiro e os subúrbios de Belém, instantaneamente começaram o mesmo procedimento, e a completa destruição de muitos lugares entrou em efeito." 
Escrivaninhas, máquinas de escrever, estantes, arquivos confidenciais, cofres, utensílios domésticos, fotografias e outros objetos eram empilhados em frente a cada firma ou residência saqueada e incendiados: "a cidade imediatamente se cobriu de fumaça e cinzas".

Das potências do Eixo, a que tinha maior presença no Pará era o Japão, e o relatório dos agentes registra a morte de "seis a oito japoneses na área". Foram destruídos: a Companhia Amazonense Japonesa, a Companhia Nipônica, a Fruteira Japonesa e uma residência de família japonesa. Os alemães, porém, eram os responsáveis pelos torpedeamentos. Firmas e residências associadas a essa nacionalidade em Belém também pagaram por isso. Foram saqueadas e/ou destruídas duas empresas exportadoras de borracha (Ranninger \& Companhia e Barringer \& Companhia), a Mende Radio \& Companhia, a Fotografia Alemã, a Hoffman \& Companhia, a Companha Química de Anilinas, A Pernambucana (loja de departamentos) e três "residências de família alemã". A Krause \& Companha foi visitada três vezes pela multidão,

\footnotetext{
"mas o proprietário, supostamente judeu, tinha uma forte guarda policial de prontidão, junto com a bandeira brasileira hasteada sobre a porta principal, resultando apenas em alguns vidros quebrados."
}

Os estabelecimentos italianos atingidos foram o Salão Popular, a Fábrica de Caixas Competidora, a Alfaiataria Caliberty, o Bar X.P.T.O., a Sociedade Italiana, a Fábrica de Botões, as sapatarias Calvoza, Bela Itália, Única, Competidora, e a Boa Fama (filial da da rua 28 de setembro). A matriz desta última escapou de maiores danos, apesar de duas "visitas" da multidão:

\footnotetext{
"o proprietário tendo seu filho, oficial do Exército Brasileiro, junto com forte guarda policial, bandeira brasileira e retrato do presidente da República, resultou apenas na destruição da grande vitrine. "
}

Ao final da tarde, a polícia restaurou "ordem parcial ao dispersar a e colocar guardas nas casas suspeitas". A partir das 16 horas, o general Zenóbio da Costa enviou as tropas de Infantaria e Cavalaria às ruas. Por toda a noite, "as ruas da área central foram fortemente patrulhadas pelas unidades do Exército Federal usando submetralhadoras, rifles e metralhadoras".

Os jornais vespertinos saíram ao final da tarde, e neles "muitas firmas de simpatias supostamente pró-Eixo" negavam essa condição, identificando seus proprietários como "cidadãos brasileiros, judeus ou de origem judaica". 
Em alguns casos era tarde, pois "os estabelecimentos já tinham sido total ou parcialmente destruídos". A conversa geral era de que a guerra contra o Eixo tinha que ser declarada logo, e

"as lojas do centro destacavam seus sentimentos no sentido da causa democrática ao colocarem o "V" de Vitória nas suas vitrines; notou-se também que as pessoas estavam usando as bandeiras brasileira e americana nas suas lapelas e vestidos, mais do que o usual"

O motim popular de 18 de agosto também brindou Bensaude e Mattos com uma oportunidade ímpar para amealharem material das empresas dos "súditos do Eixo". Ao final da tarde, eles estabeleceram um "plano de ataque" pelo qual "material inimigo de natureza confidencial e secreta poderia ser obtido". Uniformizados, com suas armas carregadas, porretes, lanternas e com um saco de barraca "bem escondido em torno da cintura de um agente", se dirigiram à Companhia Nipônica, "quartel-general de uma grande área colonial japonesa em Acará, Santarém e outras colônias japonesas próximas". Lá chegando, observaram que montava guarda "um policial especial brasileiro (Serviço Secreto)". Puxaram conversa com ele, que reclamou de ter que vigiar a entrada do prédio por várias horas, e disse estar cansado. Os agentes

\footnotetext{
"notaram que o dito homem tinha andado bebendo e que ele estava como um humor muito irresponsável; portanto, eles tomaram ampla vantagem da situação ao obter rapidamente um quarto de garrafa de rum, que eles deram ao brasileiro e lhe disseram para ir para casa e se divertir. Logo ele estava a caminho de casa gritante 'Viva americanos'."
}

Verificando não haver "saqueadores" nas proximidades, os agentes penetraram no escritório, que continha "uma pequena sala para processamento e ampliação de fotografias". Por toda parte, viam-se "papéis, arquivos quebrados, cofres abertos e cadeados quebrados, pequenos cartões, álbuns, arquivos, pastas, mapas do Brasil, tudo em japonês, mostrando instalações de todo o país." Bensaude recolhia os materiais de interesse no corredor ao fundo do prédio e os depositava no saco de barraca, enquanto Mattos juntava material na grande sala imediatamente à direita da entrada. As atividades eram paralisadas de tempos em tempos pois "vidro quebrado e papéis, quando pisados, faziam barulho", o que poderia "levantar a suspeita da patrulha militar motorizada brasileira, que estava naquele momento patrulhando as ruas".

Por volta de 19:30, Bensaude estava agachado recolhendo material no segundo corredor do saguão principal, quando olhou para cima, e "a poucos 
pés dele estava um japonês lhe apontando uma arma", que ele deduziu ser o gerente do estabelecimento "retornando para pegar material secreto". Antes que o "intruso" pudesse perguntar ou fazer qualquer coisa, "foi atingido na cabeça com um porrete pelo Agente Especial Mattos", que passara despercebido "na escuridão extrema". O idoso japonês, inconsciente, caiu no chão, largando a arma, e foi arrastado pelos agentes até o final de um corredor fechado externo ao prédio, "onde havia pouca possibilidade de alguém localizá-lo durante a noite". ${ }^{51} \mathrm{O}$ recolhimento de material aparentemente se estendeu também a estabelecimentos alemães e italianos. Os agentes listaram, para envio a Washington, 6 cartas pessoais em alemão e 14 recibos de filiação do Clube Alemão de Belém do Pará, além de um calendário de 1942 com foto de Mussolini. Mas o grosso do "acervo" foi obtido na Companhia Nipônica: duas revistas; três livros-texto; um memorando com papo timbrado do Consulado Japonês em Belém; diversas plantas de imóveis, mapas da Vila Balneário "Chapéu Virado", da cidade de Belém, das terras concedidas ao primeiro tenente Olavo Machado, do Brasil, da América do Sul, do estado do Pará, do Rio Acará, da Colônia de Acará e da Companhia Nipônica; arquivos e correspondência de negócios, incluindo diversos contratos de empréstimo e de compra e venda de terras. Havia também cartas, como as das senhoras Makano e Koma, cidadãs japonesas, sobre "condições em que dinheiro seria recebido"; um certificado em branco de ações da companhia; uma circular "com opiniões" e o contrato social da Companhia Nipônica.

A esse material textual, Bensaude e Mattos acrescentaram cento e cinquenta fotografias, retratando

"O interior de prédios nas colônias; relações públicas; atividades de exibição; equipamento de rádio; fotos detalhadas de agricultura; ilustrando todos os tipos de horta, produção de laticínios, e cultivo em geral; instalações sob construção nas colônias japonesas; sede (escritório principal em Belém), que inclui fotos do interior e exterior do mesmo; fotos de propriedades possuídas por japoneses nesta área; instalações de japoneses mostrando escolas, igrejas, poços de água; fábricas de telhas; estábulos; hotéis para imigrantes; etc.; navios e píeres, incluindo fotos do Navio Antonina, chegada de imigrantes japoneses, diferentes píeres e docas por toda a área." 


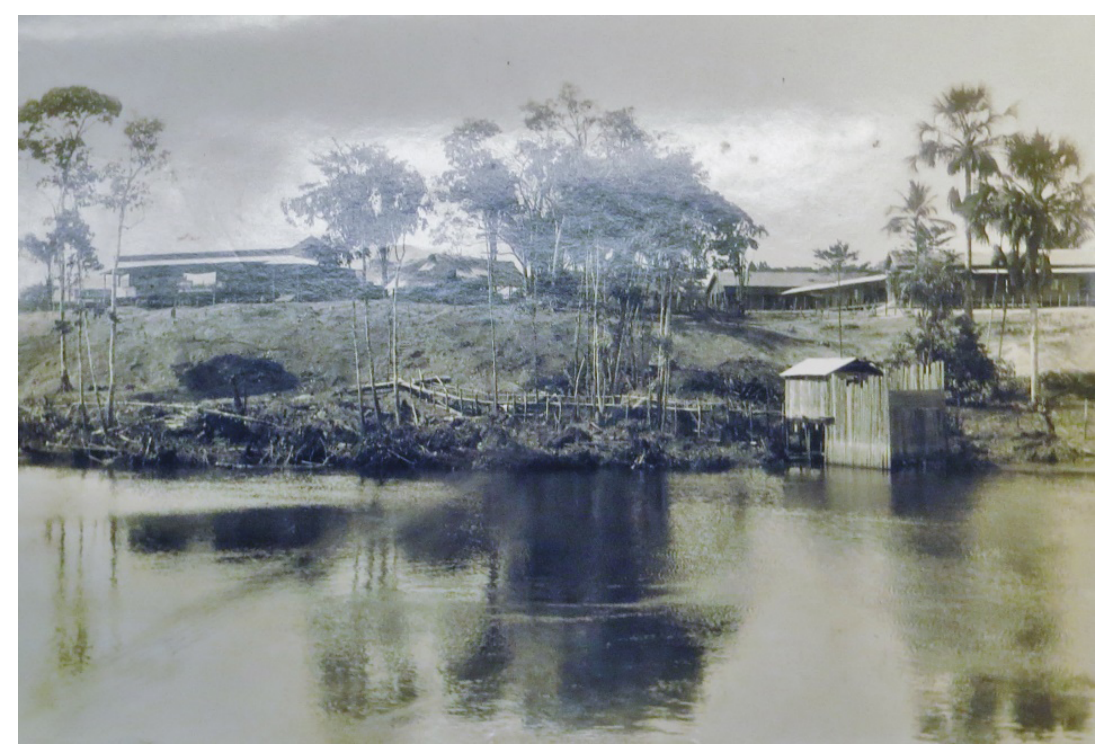

Figura 4: Fotografia de colônia japonesa no Pará, furtada pelos agentes do CIC na sede da Companhia Nipônica em 18 de agosto de 1942

O ambiente de confrontação persistiu nos dias seguintes. Albert Massler, "cidadão alemão e líder nazista bem conhecido", desapareceu "durante a violência da multidão". No dia seguinte, apareceu no Café Manduca, Rua 13 de maio, ${ }^{52} \mathrm{e}$ "começou a ridicularizar as atitudes dos brasileiros" que participaram dos eventos. Recusou-se a se retirar do local e, por conta disso "levou empurrões, teve seus óculos quebrados e ficou machucado", até fugir do café "perseguido por vários indivíduos". Ludwig Nocher, outro acusado de "Quinta Colunista" foi aprisionado junto com outros indivíduos na delegacia de polícia em meio ao tumulto. Na noite seguinte, cometeu suicídio.

A ação das massas gerou fortes repercussões em Belém. "Por todos os cafés, hotéis, esquinas e no Distrito da Luz Vermelha, as pessoas se congregavam e discutiam". Alguns diziam "que os exércitos federal e estadual não deveriam ter participado da excitação geral", e chamavam o general Zenóbio da Costa de "fascista", por ter sido supostamente leniente. Para outros, "a multidão deveria ter levado em custódia os proprietários dos estabelecimentos próEixo, ao invés de destruir suas propriedades". Havia, porém, quem estivesse "de pleno acordo com o que tinha acontecido" tanto em relação à ação da multidão quanto "ao atraso na chegada das tropas". Para Bensaude e Mattos, a visão de que "as manifestações que ocorreram dia 18 de agosto de 1942 foram puramente organizadas pelas classes mais baixas do povo, que sempre agem desta forma grosseira" era uma tentativa de desqualificação do movimento por parte da "grande rede clandestina" integralista. Os seguidores de Plínio Salgado manteriam sua força "na tropa do Exército Brasileiro, assim como no ramo oficial", na Marinha, em "firmas e casas de negócios", assim como em "todos os ramos do governo estadual e federal, incluindo escolas, prefeituras". 
A situação era tal que, na visão dos agentes, as autoridades locais operavam "de modo duplo", buscando "um equilíbrio entre o governo existente e os integralistas para manter seus cargos".

Após a decretação do "Estado de Beligerância", dia 22 de agosto de 1942, os agentes observaram que "a atitude geral assumida pela população de Belém" permanecia "variada". Alguns estavam "contentes com a ação adotada pelo Governo brasileiro", outros diziam "que o Brasil praticamente não tem defesas, e que tal declaração era suicídio”. Muitos, mesmo concordando,

\begin{abstract}
"estavam altamente intimidados pela transmissão em português de Berlim dizendo que o afundamento de navios na costa do Brasil era em comemoração ao Dia de Caxias, e que no 7 de setembro o Rio de Janeiro e pontos estratégicos passariam por um Dia de São João (dia de grandes fogos)."
\end{abstract}

De todo modo,
"A atitude geral da população nativa contra os americanos passou por uma tremenda mudança. Os donos de lojas do centro têm enfatizado sua unidade com as Nações Aliadas dando um jeito de acomodar a bandeira americana ao lado da bandeira brasileira nas suas lojas e o "V" de Vitória nas suas vitrines. Por toda a cidade, onde quer que se encontrem reuniões sociais, a população nativa expressa grande amizade em direção aos soldados americanos e os convites para festas nos teatros e jantares se tornaram mais frequentes".

Na Semana da Pátria, ao invés do prometido bombardeio alemão, o nacionalismo reassumiu a coloração ordeira e oficial mais usual do Estado Novo. No dia cinco de setembro, desfilaram "todas as escolas, dos graus iniciais até a Escola de Medicina com bandeiras do Brasil e cantando o hino nacional". Na tarde do mesmo dia, ocorreu "uma enorme parada consistindo de grupos de todas as grandes casas de negócios e firmas" enquanto o público exibia bandeiras brasileiras, portuguesas, americanas e inglesas, bem como "cartazes de todos os tamanhos louvando Getúlio Vargas, o governo brasileiro, as Nações Unidas e a causa democrática". No domingo, dia seis, houve serviços religiosos todo o dia e "todos os brasileiros leais compareceram". 
Por fim, no dia sete de setembro, às 8 da manhã, a multidão se aglomerou por muitos quarteirões esperando pela Parada Militar que começou aproximadamente às 9:10. Toda a população estava entusiasmada e animada e todos estavam agitando uma bandeira do Brasil, e o pôster "Salve Brasil" e vestindo o "V" de Vitória. Estima-se por alto que 150.000 espectadores estivessem presentes, uma das maiores concentrações que Belém testemunhou em muitos meses. ${ }^{53}$

As autoridades nacionais presentes incluíam José Malcher, governador do Estado; o general Zenóbio da Costa, comandante geral da $8^{\text {a }}$ Região Militar; seu auxiliar, o tenente coronel Castro; o marechal Gustavo Goulart, comandante da Base Naval; o brigadeiro Savaget, "chefe do Ar"; o coronel Henrique Dufles Lott comandante do $26^{\circ}$ Batalhão de Cavalaria; Abelardo Conduru, prefeito de Belém. Ao seu lado, perfilavam as autoridades norte-americanas: coronel Burt, C.O. das tropas americanas; coronel Cairns e sua equipe, comandante Breed e equipe do Observatório Naval Norte-Americano, dentre outros. Soou um salvo de 21 tiros de $75 \mathrm{~mm}$ num caminhão de 2 toneladas, tocaram as bandas do $26^{\circ}$ e $27^{\circ}$ Batalhões de Cavalaria. Desfilaram, dentre outros, um batalhão de reservistas do CPOR, marinheiros e fuzileiros dos navios "Amapá" e "Mário Alves" e 125 homens da base aérea.

\section{Considerações Finais}

Valendo-se de uma fonte inédita e singular, este texto visa contribuir para o conhecimento sobre a atuação da inteligência militar norte-americana no Brasil durante a Segunda Guerra Mundial. Essa incursão pela história da espionagem tem, entretanto, a particularidade de colocar o foco nos jovens executores de uma missão pontual, e não nos grandes arquitetos de sistemas de inteligência, cujas trajetórias atiçam a imaginação acadêmica, literária e cinematográfica, tais como J. Edgar Hoover, William J. Donovan e William Stephenson.

A base aérea norte-americana instalada em Belém durante a Guerra redefiniu momentaneamente o papel da cidade na geopolítica mundial. A capital paraense, naquele momento, se converteu em ponto estratégico no sistema de transporte de tropas e suprimentos com o qual os norte-americanos alicerçaram sua atuação na luta contra o Eixo. Esse sistema, por sua vez, deu origem à rede de bases militares em território estrangeiro, de papel decisivo na Guerra Fria e que continua a ser vital para a hegemonia militar global dos EUA. O relato minucioso de Bensaude e Mattos sobre suas ações e as informações que consideraram relevante registrar, nos ajudam a compreender a natureza da Segunda Guerra Mundial. A "guerra civil internacional”,54, na definição de 
Hobsbawm, perpassava o conjunto do tecido social mesmo em um cenário aparentemente distante das frentes de combate.

O caráter pitoresco desses relatos pode ser ilusório. É pouco provável que o óleo de fígado de tubarão vendido pelo pescador Tito em Salinas tenha desempenhado papel relevante na ação dos submarinos alemães; ninguém sabe o que Hans Meyer leu nas linhas das mãos da prostituta Louisa; e quaisquer que fossem as lealdades políticas do sírio John Homsi ou do engenheiro Bibiano, elas também não parecem ter afetado a evolução do conflito mundial. A galeria de personagens e relacionamentos reconstituídos nos relatórios dos agentes fornece, porém, um retrato fidedigno do ambiente no qual a inteligência das forças beligerantes colhia informações. Processadas e filtradas, pistas insólitas acabariam se demonstrando úteis para o planejamento de ações sigilosas, eventualmente de alto impacto, como exemplificado pelo episódio da falsa “carta da Lati” que a inteligência britânica fez chegar às mãos de Getúlio Vargas.

Mas são os motins populares de 18 de agosto de 1942, relatados pelos dois agentes em primeira mão, que demonstram o poder latente dos fluxos que a Guerra alimentava na sociedade brasileira. $\mathrm{O}$ afundamento dos navios brasileiros serviu como elemento catalisador para desencadear a emergência uma nova força que viria a alterar o cenário político nacional nas décadas seguintes. Esse contexto singular levaria à inédita sanção tácita ou explícita do Estado para o protagonismo popular nas ruas, desestabilizando a engenharia institucional criada a partir de 1930. Se em 1945 essa dinâmica tensa e contraditória custou a Getúlio Vargas seu lugar no Palácio do Catete, na década seguinte o traria de volta "nos braços do povo" e, após o suicídio, eternizaria seu lugar na história.

Foi um nacionalismo peculiar, gestado num momento em que o Estado brasileiro aceitava enclaves norte-americanos em alguns dos seus principais centros urbanos. A bandeira dos Estados Unidos era hasteada e carregada no peito junto à do Brasil, e autoridades militares ianques ocupavam a metade do palanque no desfile de Sete de Setembro. Passada a lua-de-mel da declaração de guerra contra um inimigo comum, o sentimento antiimperialista logo se voltaria contra os próprios norte-americanos, vistos com um misto de admiração e ressentimento.

Esse nacionalismo de massas, de um lado, forneceu as bases para uma compreensão ampliada de cidadania que viria a tornar mais efetiva a promessa de direitos sociais. Porém, no afã de identificar o "inimigo" ou o "suspeito", a ação das massas, com conivência do Estado e dos aliados estrangeiros, desembocou em graves violações dos direitos, não apenas de estrangeiros inocentes, mas também de cidadãos brasileiros privados de seus direitos em função de sua identidade étnica. Se em alguns casos as "fronteiras étnicas" coincidiam com as de classe e a ação nacionalista fortaleceu as organizações 
de trabalhadores, em outros, como parece ter sido o caso de Belém, os "súditos do Eixo" serviram de bodes expiatórios para a indignação popular, alimentada pela carestia, pelo mercado negro e pela restrição do exercício de diversos direitos civis e trabalhistas.

Não sabemos avaliar a contribuição da missão de Bensaude e Mattos para o planejamento futuro das ações da inteligência militar norte-americana. Mas ela nos legou, involuntariamente, uma importante fonte para a compreensão de fenômenos ainda pouco conhecidos da história do Brasil no contexto da Segunda Guerra Mundial.

\section{NOTAS}

1 Examinei essas questões historiográficas em dois trabalhos recentes: FORTES, A. "Os impactos da Segunda Guerra Mundial e a regulação das relações de trabalho no Brasil." Nuevo Mundo Mundos Nuevos [En ligne], 2014; FORTES, A. Do reformismo tecnocrático ao nacionalismo de massas: A Segunda Guerra Mundial e a emergência do trabalhismo brasileiro. In. A questão nacional e as tradições nacional-estatistas no Brasil, América Latina e África. FERRERAS, N.. Rio de Janeiro, Editora FGV

Faperj, 2015, pp. 67-88.

2 Realizado com apoio do CNPq (Bolsa de Produtividade em Pesquisa, Edital Universal e Edital de Ciências Humanas).

3 “Assignment - Brazil; Bensaude - Mattos. 5 de novembro de 1942, Washington, D.C.". National Archives and Records Administration, Record Group 319 (Records of the Army Staff), Entry NMr347c, Box 225.

4 MCCANN, F. D. The Brazilian-American alliance, 1937-1945, [Princeton, N.J.] Princeton University Press, [1974, c1973], p. 117.

5 HUGGINS, M. K. Polícia e política: relações Estados Unidos América Latina. São Paulo: Cortez, 1998, p. 69.

6 TOTA, A. P., et al. The seduction of Brazil : the Americanization of Brazil during World War II. Austin, University of Texas Press, Teresa Lozano Long Institute of Latin American Studies, 2009, p. 44, 52-56, 70, 113.

7 Ibid, p. 50-56.

8 National Archives and Records Administration, Record Group 216 (Office of Strategic Services).

9 É interessante notar, por exemplo, que no seu clássico trabalho de sobre "espionagem alemã" e "contraespionagem aliada" no Brasil durante a Guerra, Stanley Hilton mencione a OSS apenas em uma ocasião, que diz respeito ao monitoramento das atividades políticas de Plínio Salgado em Lisboa. HILTON, S. E. Hitler's secret war in South America, 1939-1945: German military espionage and Allied counterespionage in Brazil. Baton Rouge: Louisiana State University Press, 1981, p. 272-276.

10 LOCHERY, N. Brazil : the fortunes of war : World War II and the making of modern Brazil, p. 97. 
11 HUGGINS, M. K. Polícia e politica: relações Estados Unidos América Latina. São Paulo: Cortez, 1998, p. 69-79. Dados biográficos de Milano podem ser consultados em: http:// ijuisuahistoriaesuagente.blogspot.com.br/2012/09/serie-dr-martin-fischer-04-plinio.html, acessado em 09 de fevereiro de 2016. A notícia de sua morte em Montevidéu, quando já ocupava o cargo de subprefeito de Porto Alegre, sem qualquer menção às circunstâncias da mesma, foi divulgada pela imprensa, tal como em matéria de capa do jornal "A Noite" de 23 de outubro de 1944. Disponível em: http://memoria.bn.br/DocReader/Hotpage/HotpageBN. aspx?bib=348970_04\&pagfis=29977\&pesq=\&url=http://memoria.bn.br/docreader\# , acesso em 09 de fevereiro de 2016.

12 HILTON, S. E. Hitler's secret war in South America, 1939-1945: German military espionage and Allied counterespionage in Brazil. Baton Rouge, Louisiana State University Press, 1981.

13 STEPHENSON, W. S. British security coordination: the secret history of British intelligence in the Americas, 1940-1945. New York, Fromm International, 1999, p. 4.

14 Ibid, p. 24-46

15 Ibid, Mapa incluído à página XXIX.

16 Ibid, p. 288-294.

17 Ibid, p. 294-298.

18 FALCÃO, J. O Brasil e a Segunda Guerra Mundial: testemunho e depoimento de um soldado convocado. Brasília, Editora UnB, 1998.

19 https://en.wikipedia.org/wiki/Counterintelligence Corps, acesso em 21 de fevereiro de 2016.

20 https://en.wikipedia.org/wiki/South_Atlantic air ferry route in World War II\#/media/ File:AirFerryRoutesOfWWII.png, acesso em 21 de fevereiro de 2016.

21 Counter Intelligence Corps. History and Mission in World War II. The Counter Intelligence Corps School, Fort Holabird Baltimore 19, Maryland, 1951. Disponível em http://www.dtic. mil/dtic/tr/fulltext/u2/a439224.pdf , acesso em 10 de fevereiro de 2016.

22 HERMAN, R.. In Defense of Sovereignty: Labor, Crime, Sex and Nation at U.S. Military Bases in Latin America, 1940-1947. History Department. Berkeley, University of California, PhD, 2014.

23 Counter Intelligence Corps. History and Mission in World War II. The Counter Intelligence Corps School, Fort Holabird Baltimore 19, Maryland, 1951. Disponível em http://www.dtic. mil/dtic/tr/fulltext/u2/a439224.pdf, acesso em 10 de fevereiro de 2016.

24 “Assignment - Brazil; Bensaude - Mattos. 5 de novembro de 1942, Washington, D.C.". National Archives and Records Administration, Record Group 319 (Records of the Army Staff), Entry NMr347c, Box 225. As informações mencionadas neste e nos próximos itens provêm desse relatório, exceto quando outras fontes são indicadas em notas específicas.

25 https://aad.archives.gov/aad/record-detail.jsp?dt=893\&mtch=1\&cat=all\&tf=F\&q=jose+be nsaude $+12021075 \& \mathrm{bc}=\& \mathrm{rpp}=10 \& \mathrm{pg}=1 \& \mathrm{rid}=491523 ;$ https: $/ /$ aad.archives.gov $/ \mathrm{aad} / \mathrm{record}-$ detail.jsp?dt=893\&mtch $=11 \& \mathrm{tf}=\mathrm{F} \& \mathrm{q}=$ Anthony $\& \mathrm{bc}=\&$ sort $=24996 \% 20 \mathrm{desc} \& \mathrm{rpp}=50 \& \mathrm{pg}=1$

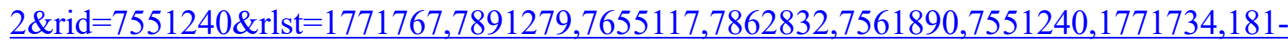
$\underline{8933,7854302,1818929}$, acesso em 21 de fevereiro de 2016. 
$26 \mathrm{http} / /$ www.rootsweb.ancestry.com/ cagha/obits/stanislaus/obits/obits-mz/mattosanthony-r.txt; $;$ http://onlinelibrary.wiley.com/doi/10.1111/j.1540-4781.1962.tb01776.x/abstract , acesso em 21 de fevereiro de 2016.

27 Correio da Manhã, 25 de janeiro de 1948, p. 6. Disponível em: http://memoria.bn.br/ DocReader/Hotpage/HotpageBN.aspx?bib=089842 05\&pagfis $=39915 \& p e s q=\& u r l=h t t p: / /$ memoria.bn.br/docreader\#, acesso em 21 de fevereiro de 2016.

28 A Noite, 09 de março de 1950, p. 11. Disponível em: http://memoria.bn.br/DocReader/ Hotpage/HotpageBN.aspx?bib=348970 05\&pagfis $=849 \&$ pesq $=\& u r l=h t t p: / /$ memoria.bn.br/ docreader\#, acesso em 21 de fevereiro de 2016.

29 Correio da Manhã, 12 de março de 1950, p. 3. Disponível em: http://memoria.bn.br/ DocReader/Hotpage/HotpageBN.aspx?bib=089842 06\&pagfis=1278\&pesq=\&url=http:// memoria.bn.br/docreader\#, acesso em 21 de fevereiro de 2016.

30 Diário Oficial da União, 27 de maio de 1950. http://www.jusbrasil.com.br/diarios/2513761/ pg-36-secao-1-diario-oficial-da-uniao-dou-de-27-05-1950, Seção 1, p. 36.

31 http://alfredobensaude.ist.utl.pt/nucleos/nucleo/id/1/paginaid/12, acesso em 21 de fevereiro de 2016.

32 http://www.acad-ciencias.pt/wordpress/wp-content/uploads/2014/04/Alfredo-Bensaude. pdf, acesso em 21 de fevereiro de 2016.

33 Em entrevista concedida ao projeto Cientistas Sociais de Países de Língua Portuguesa do CPDOC-FGV, em 2010, Manuel Villaverde Cabral registra que em 1940 as atividades dos Bensaude nos Açores ainda se concentravam na agroindústria de tabaco e chá: http://www. fgv.br/cpdoc/historal/arq/Entrevista1786_2.pdf, acesso em 21 de fevereiro de 2016.

34 Originalmente "Sociedade Açoriana de Estudos Aéreos".

35 https://pt.wikipedia.org/wiki/Jos\%C3\%A9_Bensaude; http://www.sabado.pt/dinheiro/ detalhe/de uma_judiaria_em_marrocos_nasceu_um imperio_nos_acores.html; http://www. seer.ufrgs.br/webmosaica/article/viewFile/43104/27206, acesso em 21 de fevereiro de 2016.

36 National Archives and Records Administration. Records of the Office of Strategic Services (Record Group 226) 1940- 1947. Descrição do conteúdo de 538 caixas referentes à Entry 210. Disponível em https://www.archives.gov/iwg/declassified-records/rg-226-oss/entry-210.pdf, acesso em 21 de fevereiro de 2016.

37 National Archives and Records Administration. Records of the Office of Strategic Services (Record Group 226) 1940- 1947. https://www.archives.gov/iwg/declassified-records/rg-226oss/directors-microfilm-roll-list.pdf, acesso em 21 de fevereiro de 2016.

38 ROCHA, A. L. M. Alliances équivoques et rivalités anglo-américaines au cour de l'Atlantique L'archipel des Açores entre Seconde Guerre mondiale et Guerre froide (19421948). Paris, Université Paris 1 - Panthéon-Sorbonne, Doutorado em História, 2012, p. 170, 221.

39 Por questões de espaço, não há como tratar aqui do lugar da Amazônia nas relações entre Brasil e Estados Unidos durante a Segunda Guerra Mundial. Seth Garfield demonstrou de forma magistral como a necessidade de recorrer à borracha brasileira em função da dominação japonesa sobre as fontes de produção asiáticas envolveu não apenas o atendimento a uma demanda vital para a defesa norte-americana, mas também o enfrentamento entre concepções divergentes sobre a viabilidade e pertinência do investimento num pan-americanismo “desenvolvimentista” para a região. Garfield, S. (2009). "A Amazônia no imaginário norte- 
americano em tempo de guerra." Revista Brasileira de História 29, pp. 19-65.

40 Sobre a história das "Estações Profiláticas" do Exército norte-americano desde a Primeira Guerra Mundial, ver: http://historianovest.blogspot.com.br/2010/11/em-casa-de-doencavenerea-1914-1918 22.html, acesso em 21 de fevereiro de 2016. Herman identifica as relações sexuais entre os soldados estrangeiros e mulheres nativas como um dos principais pontos de tensão surgidos entre a jurisdição norte-americana das bases e a soberania dos países nos quais elas se localizavam. Os demais eram direitos trabalhistas, relações raciais e crimes: Herman, R. (2014). In Defense of Sovereignty: Labor, Crime, Sex and Nation at U.S. Military Bases in Latin America, 1940-1947. History Department. Berkeley, University of California, Berkeley. PhD

41 Ao longo de todo o relatório dos agentes do CIC, a grafia usada para descrever a região da Base Aérea é "Val de Caes". Atualizamos para o padrão atualmente utilizado na denominação do Aeroporto Internacional de Belém: "Val-de-Cans".

42 https://cpdoc.fgv.br/producao/dossies/AEraVargas2/biografias/Zenobio_da_Costa. Acesso em 21 de fevereiro de 2016.

$43 \mathrm{https} / /$ cpdoc.fgv.br/producao/dossies/AEraVargas2/biografias/caiado_de_castro. Acesso em 21 de fevereiro de 2016.

$44 \mathrm{O}$ armamento efetivamente instalado nas semanas seguintes era constituído por Três metralhadoras calibre .50 e três metralhadoras calibre .30, sendo apenas uma delas antiaérea.

45 Para enfatizar a importância política de Martins, o relatório cita que ele havia sido nomeado recentemente pelo ministro João Alberto, coordenador de mobilização econômica, para ir ao Canadá em missão.

46 Sobre a trajetória política de Conduru, ver: http://mosqueirando.blogspot.com.br/2014/02/ na-rota-da-historia-abelardo-leao.html. Acesso em 21 de fevereiro de 2016.

47 PERAZZO, P. F. Prisioneiros da guerra: os "Súditos do eixo" nos campos de concentração brasileiros (1942-1945). São Paulo, Humanitas: Imprensa Oficial, 2009; SILVA, H., et al. Por terra, céu e mar: Histórias e memórias da Segunda Guerra Mundial na Amazônia. Belém, Paka-Tatu, 2014.

48 Mário Chermont filho de uma tradicional família política paraense, foi dos líderes da Revolução de 1930 no estado e integrou a junta governativa por ela instalada juntamente com seu primo, Abel Chermont. Posteriormente, foi nomeado secretário-geral da Educação e da Saúde Pública no governo do tenente Joaquim de Magalhães Barata. Em 1945, viria a se filiar ao Partido Trabalhista Brasileiro (PTB). Já Abel teve papel de liderança na oposição à repressão contra a Aliança Nacional Libertadora (ANL) em 1935, e viria a ser eleito suplente de senador na chapa de Luís Carlos Prestes, pelo Partido Comunista do Brasil (PCB), dez anos depois. http://cpdoc.fgv.br/sites/default/files/verbetes/primeira-republica/CHERMONT,\%20 M\%C3\%A1rio\%20r\%20(1).pdf Acesso em 21 de fevereiro de 2016.

49 O salesiano Davino Ferreira tivera recentemente passagem tumultuada por Juazeiro (CE), onde fora acusado de comandar um "novo surto de fanatismo" na terra do Padre Cícero. Ferreira rebateu as acusações dizendo que iniciara a campanha em favor de "Cristo Rei" para combater a atuação de "elementos contrários à doutrina de Jesus" que vinham "fazendo torpe exploração das populações sertanejas, apregoando que Cristo Rei era um comunista, um rei da Rússia”. Diário da Noite, 17 de janeiro de 1941. P. 3. Disponível em http://memoria.bn.br/ DocReader/Hotpage/HotpageBN.aspx?bib=221961 02\&pagfis=5891\&pesq=\&url=http:// memoria.bn.br/docreader\#. Acesso em 21 de fevereiro de 2016.

50 Aluísio da Costa Chaves viria a ser governador do Pará durante a Ditadura Militar. https:// pt.wikipedia.org/wiki/Alu\%C3\%ADsio_da_Costa_Chaves. Acesso em 21 de fevereiro de 
2016.

51 Uma síntese do episódio foi relatada em Gilbert, J. L., Finnegan, J. P., Bray, A., \& United States. (2005). In the shadow of the sphinx: A history of Army counterintelligence. Fort Belvoir, Va: History Office, Office of Strategic Management and Information, US Army Intelligence and Security Command, p. 73. Sem citar os nomes de nenhum dos dois, o relato inverte os papéis de Bensaude e Mattos, descrito como "um agente secreto do CIC, que na vida real era um professor de línguas", na ação.

52 Sobre o Café Manduca, ver https://pt.wikipedia.org/wiki/Caf\%C3\%A9_Manduca_-_Uma_ Hist $\%$ C3\%B3ria_Recontada, acesso em 21 de fevereiro de 2016.

53 A mesma estimativa de público foi dada por Mattos para o Círio de Nazaré (que ele denomina de "Festival de Santa Nazareth") no mês seguinte.

54 Hobsbawm, E. (1996). Era dos extremos: O breve século XX, 1914-1991. São Paulo, Companhia das Letras.

Artigo recebido em outubro de 2015. Aceito em janeiro de 2016. 